\title{
Job Satisfaction and Job Performance in PT XYZ
}

\author{
Cindy Valianawaty \\ Department of Management, Faculty of Economics, \\ Petra Christian University \\ cindy_10054@yahoo.com \\ Ēddy M. Sutanto \\ Department of Management, Faculty of Economics, \\ Petra Christian University
}

\begin{abstract}
This study was aimed to describe the measurements levels of job satisfaction and job performance, as well as to examine the positive effects on job satisfaction of employees performance in PT XYZ. This study used a quantitative approach, primary data which was obtained from the questionnaires to 60 employees, and secondary data from the company record, literature and previous research. The conclusion was, first, that each of individual employees had different job satisfaction. Second, the job performance was individual. Third, job satisfaction was high, working condition indicator as the highest and social service indicator as the lowest. Fourth, job performance was high, quality of work indicator as the highest, as well as cooperative and dependability indicator as the lowest. Fifth, the job satisfaction had no positive effect on job performance in PT XYZ.
\end{abstract}

Keywords: job satisfaction, job performance

\section{INTRODUCTION}

In the current era of globalization, the issue of human resources is still in the spotlight and power for companies to remain afloat. Human resources have a major role in every activity of the company, although it is supported by the infrastructure and redundant financial resources. Without the support of reliable human resources, the company still cannot establish properly, which then only can cause inaccuracies in the company.

With this important role, human resources should be carefully managed. Between the employee and the company, there is a tendency that they should have a relationship of mutual need. Companies need qualified and productive employees. Employees need companies to be able to meet their needs. As the two parties need each other, it is necessary to create a harmonious relationship between them.

The effort of the company's management is necessary to continue to maintain and improve employee's job satisfaction. Employees need a satisfaction during their time of working, both in terms of material and morale. Work is perfectly needed as a definition the fulfillment of one personal satisfaction. When employees do not get satisfaction from the work, morale will fall and job dissatisfaction emerges, so that it's difficult for manager to get worker's cooperation. In order to establish a good job satisfaction, managers should give employees a clear job description to achieve job satisfaction.

Employees have the protection of the Government stated in UU nomor 13 tahun 2003 on Labour. This law provides labor protection to ensure the basic rights of workers/laborers and ensure similarity, opportunity and non-discrimination in order to realize worker's families' welfare, regarding to developmental progress of the business world. The Law (UU) also covers wages, and employee benefits. Job satisfaction is the important variable to achieve by organizations (Chen, Zhao \& Liu, 2012). Unsatisfactory made unefficiency and ineffectively organizations (Hooi, 2007; Vrinda \& Jacob, 2015).

Job satisfaction itself has a definition that is difficult to define on simplest term. For employees, job satisfaction appears when the perceived benefits of work could exceed the marginal costs that have been incurred, which employee considered adequate. According to Hasibuan (2007), job satisfcation is described as an emotional attitude of fun and loves for one's job. In line with this, Noe et al. (2008) defined job satisfaction 
as a pleasant feeling of the result of the perception that his work has met the important values of work. Job satisfaction is essentially individualistic. Each individual has a level of satisfaction varies according to the system value that has prevailed on. This is due to the differences in each individual. The higher the assessment of an activity considered appropriate to the individual's desire is, the higher the satisfaction with the activity.

Many factors can affect employees' job satisfaction. In this case, according to Minnesota Satisfaction Questionnaire (MSQ), there are 20 aspects of job satisfaction which are related to each other, such as ability utilization, achievement, activity, advancement, authority, company policies, compensation, co-worker, creativity, independence, moral values, recognition, responsibility, security, social service, social status, HR supervision, technical supervision, variety, and working condition. Employees' job satisfaction must be created as good as possible in order to increase better morale, dedication, passion, and discipline on employees. This attitude is reflected by morale, discipline, and job performance.

Employee's performance is most important for managers beside employee's job satisfaction (Kelidbari, Dizgah \& Yusefi, 2011). Manager must have analyze factors made high performance for organization (Abbas and Yaqoob, 2009). Wu and Lee (2011). Employee performance is defined as the employee's overall performance meets the expected quality, and the achievement of tasks based on policies and time in accordance with the provisions of the organization. In line with this, Keller (2006) stated that the way in which employees achieve the set goals of the organization and interpersonal behavior linking them with organizational norms can be termed as the employee's performance.

According to Handoko (2012), performance is the last measure of employees' success to do the job. Basically, performance is individualistic because each employee has a different ability level in doing his job, by relying on a combination of ability, effort, and opportunity gained. According to Parvin and Kabir (2011), a good leader must be a good teacher and should know how to encourage employees to improve the job performance in the workplace, and to increase the knowledge of the employees. Leaders in the company should allow their employees to reach their full potential, in this case an evaluation in the form of performance assessment.

The performance assessment is expected to help the leader to monitor the job performance both individually and as a whole group. Determination of assessment criteria should be clear and objective, therefore the assessment made has accurate results in any work activities that are assessed. Gomes (2003) described that in conducting research on a performance based on specific behavior (judgment performance evaluation), there are 8 dimensions that need to be brought up, such as quality of work, quantity of work, job knowledge, creativity, cooperative, initiative, dependability, and personal quality.

PT XYZ is a family company located in Surabaya. This company has been established for 45 years and is engaged in food distribution. The company has 60 employees in its headquarters. It has to fulfill labor standards in accordance with UUnomor 13 on Labour, where the company provided salary in accordance with the standards above the minimum wage for employees. The company should also provide benefits that every employee required in accordance with the standards. However, salaries and allowancesare not the only necessary factors determining employees' job satisfaction. There are many other necessary factors that could be the question in determining the satisfaction, especially in the current unstable economic situation during this period of time. Therefore, employess should become more intensive to do the best out of the company they work for, and so the leaders do: in improving employees' performance at work.

Based on those facts explained before, there are problems related to theh facts themselves. The first one is how is the level of satisfaction and the performance of employees in the company. This problem is still in question and requires further study because it also becomes the background of this research. The second problem is how to analyze and measure the level of employees' job satisfaction and performance. The last problem tends to show that does job satisfaction have positive influence on job performance in PT XYZ.

\section{METHODS}

Companies are expected to see any basic needs required by each employee. It is very important for the progress and improvement of productivity. The purpose of this study is to measure, test, and describe the level of satisfaction and job performance, as well as test and describe the positive effects arising from job satisfaction to job performance in PT XYZ.

The data collected in this study consists of primary data and secondary data. Primary data was obtained from the questionnaire on job satisfaction and job performance. Data taken from the questionnaire is the identity of respondents (occupation, sex, age, religion, place of origin, last education, time they had been working on), as well as the answers of the indicators of job satisfaction and job performance. Secondary data was collected from the archives of PT XYZ in the form

of organizational structure, employees' job descriptions, employees' data, and other supporting datas obtained from the company. In addition, secondary data was also obtained from the literature and the results of previous research.

This research was conducted at PT XYZ located 


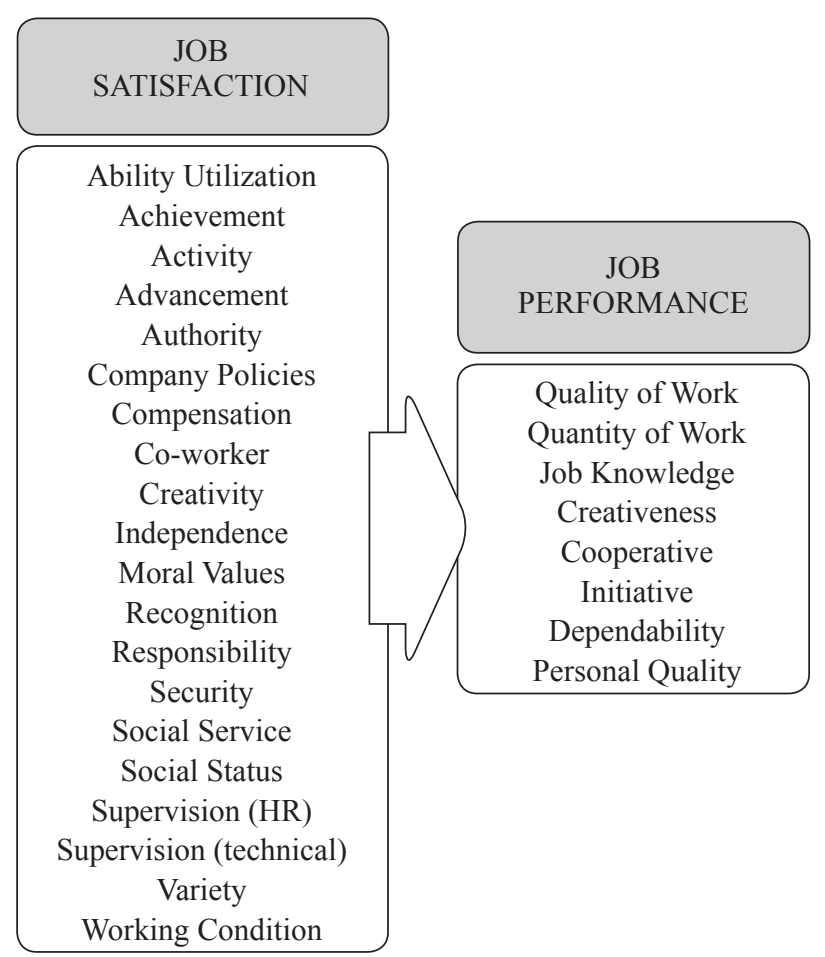

Figure 1. Research Framework

in Surabaya. Data collection technique in this study was conducted by the division of the questionnaire. Questionnaires were distributed as measurements using the rating scale with a Likert-type scale.

The determination of sample for this study is with the distribution of questionnaires. Job satisfaction questionnaire filling was distributed to the entire population of employees at PT XYZ, as many as 60 employees in six departments. Job performance questionnaire filling was distributed to nine managers of 6 departments; these managers will discuss/review the employee one by one of different departments. Manager's performance questionnaire filling will be reviewed by the owner.

Data analysis techniques in the study were carried out by first identifying the identity of the respondents. Identifying the respondent's identity was divided into the information about occupation, sex, age, religion, place of origin, recent education and time they had been working on.The type of this research is quantitative research. The data analysis used for this research is SPSS for Windows Ver. 19.0. Data analysis technique is done by measuring the appropriateness of the data used. These measurements are using analysis of validity and reliability, as well as normality and heteroscedasticity test.

Validity analysis isuseful to measure whether the questionnaires are validor not or not. Reliability analysis is useful for measuring reliability of data that was used. Normality test is useful for measuring whetherthe distribution of data is normal or not. Heteroscedasticity test is useful for measuring whether the data used homogeneous or not.This study uses job satisfaction as the independent variables with the symbol $\mathrm{X}$, and job performance as the dependent variable with the symbol Y. The method of data analysis for both variables X and $\mathrm{Y}$ in this study is using simple linear regression analysis to test hypothesis using $t$ test.

\section{RESULTS}

PT $\mathrm{XYZ}$ is a family company that is engaged in the distribution of food ingredients and beverages. The companyis now managed by the third generation and has been established for more than 45 years. In the beginning of establishment, PT XYZ started with a small retail store located in the heart of Chinatown in Surabaya, which then in 1977 switched the business from small retail businesses to suppliers of food and drink, until finally in 1992 the company restructured to PT (perseroan terbatas/incorporated company). The company has a mission that is supported by the company's vision, namely to become a favorite (most preferred) supplier to supply foodstuffs and beverages in Indonesia.

The respondents who had completed questionnaires are identified by occupation, sex, age, religion, place of origin, recent education and time they had been working. Employees in XYZ consist of 60 people who had 9 managers from six departments: with the procentage of male employees is $36.7 \%$ and $63.3 \%$ of female employees. Employees at the company are divided into age as much as $75.0 \%$ of $20-35$ years, and older than 35 years as much as $25.0 \%$, with employees working longer than 5 years of $26.7 \%, 6-15$ years amounting to $60.0 \%$, and over 15 years of $13.3 \%$. A total of $78.3 \%$ of employees are employees who are originated from Surabaya, and as much as $31.7 \%$ of Christian.

Table 1. Employees Position Distribution in PT XYZ

\begin{tabular}{lcccc}
\hline \multirow{2}{*}{ Position } & \multicolumn{2}{c}{ Job Satisfaction } & \multicolumn{2}{c}{$\begin{array}{c}\text { Job } \\
\text { Performance }\end{array}$} \\
\cline { 2 - 5 } & Unsatisfactory & Satisfactory & Low & High \\
\hline Accounting & $0 \%$ & $11,7 \%$ & $1,7 \%$ & $10,0 \%$ \\
Export & $0 \%$ & $6,7 \%$ & $0 \%$ & $6,7 \%$ \\
Import & $0 \%$ & $13,3 \%$ & $1,7 \%$ & $11,7 \%$ \\
Finance & $1,7 \%$ & $3,3 \%$ & $1,7 \%$ & $3,3 \%$ \\
HRD & $0 \%$ & $6,7 \%$ & $0 \%$ & $6,7 \%$ \\
IT & $1,7 \%$ & $55,0 \%$ & $0 \%$ & $56,7 \%$ \\
Sales & & & &
\end{tabular}

Table 2. Employees Gender Distribution in PT XYZ

\begin{tabular}{lcccc}
\hline \multirow{2}{*}{ Gender } & \multicolumn{2}{c}{ Job Satisfaction } & \multicolumn{2}{c}{ Job Performance } \\
\cline { 2 - 5 } & Unsatisfactory & Satisfactory & Low & High \\
\hline Man & $0 \%$ & $36,7 \%$ & $1,7 \%$ & $35,0 \%$ \\
Woman & $3,3 \%$ & $60,0 \%$ & $3,3 \%$ & $60,0 \%$ \\
\hline
\end{tabular}


Table 3. Employees Age Distribution in XYZ

\begin{tabular}{ccccc}
\hline \multirow{2}{*}{ Age } & \multicolumn{2}{c}{ Job Satisfaction } & \multicolumn{2}{c}{ Job Performance } \\
\cline { 2 - 5 } & Unsatisfactory & Satisfactory & Low & High \\
\hline 20 -35 у.о & $3,3 \%$ & $71,7 \%$ & $5,0 \%$ & $70,0 \%$ \\
$>35$ у.о & $0 \%$ & $25,0 \%$ & $0 \%$ & $25,0 \%$ \\
\hline
\end{tabular}

Table 4. Employees Religion Distribution in PT XYZ

\begin{tabular}{lcccc}
\hline \multirow{2}{*}{ Religion } & \multicolumn{2}{c}{ Job Satisfaction } & \multicolumn{2}{c}{ Job Performance } \\
\cline { 2 - 5 } & Unsatisfactory & Satisfactory & Low & High \\
\hline Buddha & $0 \%$ & $15,0 \%$ & $1,7 \%$ & $13,3 \%$ \\
Islam & $3,3 \%$ & $21,7 \%$ & $1,7 \%$ & $23,3 \%$ \\
Catholic & $0 \%$ & $28,3 \%$ & $0 \%$ & $28,3 \%$ \\
Christian & $0 \%$ & $31,7 \%$ & $1,7 \%$ & $30,0 \%$ \\
\hline
\end{tabular}

Table 5. Employees Origin Distribution in PT XYZ

\begin{tabular}{lcccc}
\hline \multirow{2}{*}{$\begin{array}{c}\text { Place Of } \\
\text { Origin }\end{array}$} & \multicolumn{2}{c}{ Job Satisfaction } & \multicolumn{2}{c}{ Job Performance } \\
\cline { 2 - 5 } & Unsatisfactory & Satisfactory & Low & High \\
\hline Banyuwangi & $0 \%$ & $1,7 \%$ & $1,7 \%$ & $0 \%$ \\
Jember & $0 \%$ & $1,7 \%$ & $0 \%$ & $1,7 \%$ \\
Jombang & $1,7 \%$ & $1,7 \%$ & $0 \%$ & $3,3 \%$ \\
Kupang & $0 \%$ & $1 ., 7 \%$ & $0 \%$ & $1.7 \%$ \\
Madiun & $0 \%$ & $5,0 \%$ & $0 \%$ & $5,0 \%$ \\
Magelang & $0 \%$ & $1,7 \%$ & $0 \%$ & $1,7 \%$ \\
Malang & $0 \%$ & $3,3 \%$ & $0 \%$ & $3,3 \%$ \\
Mojokerto & $0 \%$ & $1,7 \%$ & $1,7 \%$ & $0 \%$ \\
Surabaya & $1,7 \%$ & $76,7 \%$ & $1,7 \%$ & $76,7 \%$ \\
Tuban & $0 \%$ & $1,7 \%$ & $0 \%$ & $1,7 \%$ \\
\hline
\end{tabular}

Table 6. Employees Last Education Distribution in PT XYZ

\begin{tabular}{lcccc}
\hline \multirow{2}{*}{$\begin{array}{c}\text { Last } \\
\text { Education }\end{array}$} & \multicolumn{2}{c}{ Job Satisfaction } & \multicolumn{2}{c}{ Job } \\
\cline { 2 - 5 } & Unsatisfactory & Satisfactory & Low & High \\
\hline Senior High & $0 \%$ & $11,7 \%$ & $0 \%$ & $11,7 \%$ \\
School & $0 \%$ & $71,7 \%$ & $5,0 \%$ & $66,7 \%$ \\
Bachelor & $3,3 \%$ & $13,3 \%$ & $0 \%$ & $16,7 \%$ \\
Diploma & & & & \\
\hline
\end{tabular}

Table 7. Employees Work Time Span Distribution in PT XYZ

\begin{tabular}{lcccc}
\hline \multirow{2}{*}{ Time Span } & \multicolumn{2}{c}{ Job Satisfaction } & \multicolumn{2}{c}{ Job Performance } \\
\cline { 2 - 5 } & Unsatisfactory & Satisfactory & Low & High \\
\hline$<5$ years & $1,7 \%$ & $25,0 \%$ & $1,7 \%$ & $25,0 \%$ \\
6-15 years & $1,7 \%$ & $58,3 \%$ & $3,3 \%$ & $56,7 \%$ \\
$>15$ years & $0 \%$ & $13,3 \%$ & $0 \%$ & $13,3 \%$ \\
\hline
\end{tabular}

Employees havelast educated of Bachelor degree as about $71.7 \%$.

Validity test is done by comparing the rcount with rtable (Priyatno, 2010). Value of rcount is the correlation result of respondents' questionnaire answers in each statemnents using using SPSS analysis. Value of $r$ table is 0.254 , with a significance of $5 \%$ and the number of samples of 60 . The calculation results of validity test stated that the indicators of job satisfaction and performance are valid. It means that these indicators have a positive value and the value $r$ count $>r$ table.

Table 8. Descriptive Statistic of Job Satisfaction

\begin{tabular}{lcc}
\hline \multicolumn{1}{c}{ Indicator } & Mean & Explanation \\
\hline Ability Utilization & 4,02 & High \\
Achievement & 3,90 & High \\
Activity & 4,03 & High \\
Advancement & 3,68 & High \\
Authority & 3,78 & High \\
Company Policies & 3,70 & High \\
Compensation & 3,70 & High \\
Co-Worker & 3,90 & High \\
Creativity & 3,88 & High \\
Independence & 3,80 & High \\
MoralValues & 3,90 & High \\
Recognition & 3,77 & High \\
Responsibility & 3,95 & High \\
Security & 3,97 & High \\
SocialService & 3,45 & High \\
SocialStatus & 3,57 & High \\
Supervision (HR) & 3,78 & High \\
Supervision (Technical) & 3,88 & High \\
Variety & 3,75 & High \\
Working Condition & 4,05 & High \\
\hline & & 3,82 \\
\hline & &
\end{tabular}

Table 9. Descriptive Statistic of Job Performance

\begin{tabular}{lcc}
\hline \multicolumn{1}{c}{ Indicator } & Mean & Explanation \\
\hline Indicator 1 & 3,83 & High \\
Indicator 2 & 3,97 & High \\
Indicator 3 & 3,85 & High \\
Indicator 4 & 3,88 & High \\
Indicator 5 & 3,62 & High \\
Indicator 6 & 3,78 & High \\
Indicator 7 & 3,65 & High \\
Indicator 8 & 3,60 & High \\
Indicator 9 & 3,80 & High \\
Indicator 10 & 3,88 & High \\
Indicator 11 & 3,80 & High \\
Indicator 12 & 3,90 & High \\
Indicator 13 & 3,60 & High \\
Indicator 14 & 3,85 & High \\
Indicator 15 & & High \\
\hline
\end{tabular}


Normal P-P Plot of Regression Standardized Residual

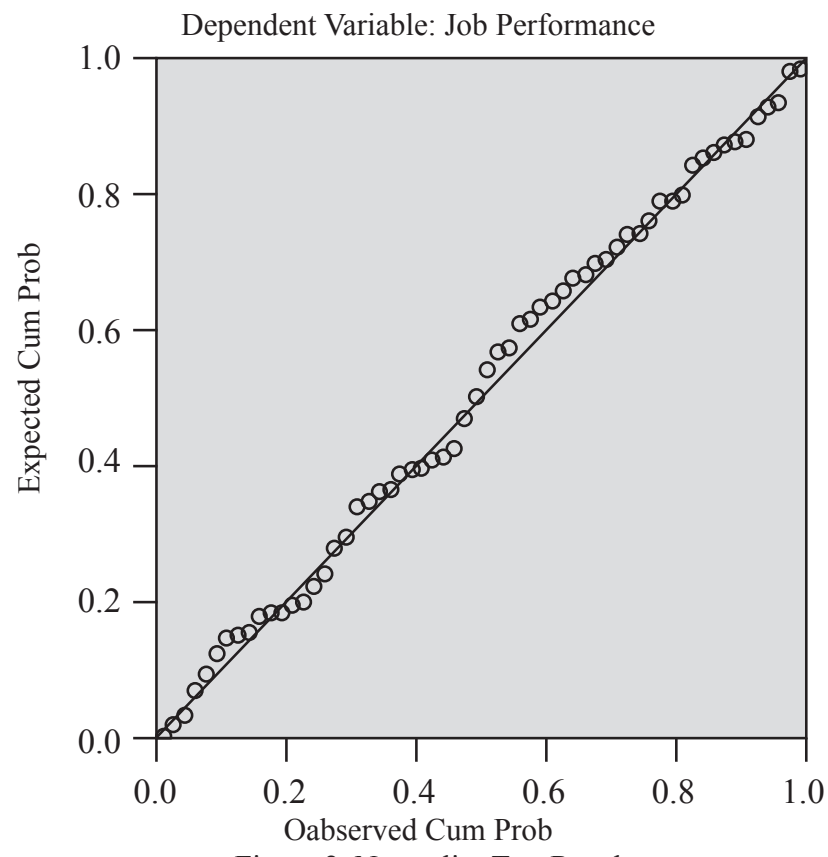

Figure 2. Normality Test Result

Scatterplot

Dependent Variable: Job Performance

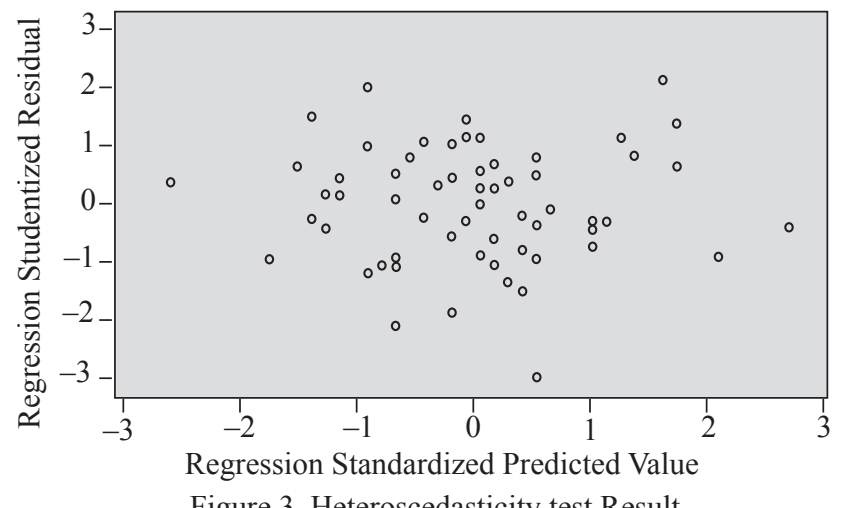

Figure 3. Heteroscedasticity test Result

Reliability test in this study indicate that the instrument of measuring job satisfaction and job performance has been reliable with a good level of reliability, which means the value of Cronbach's Alpha on job satisfaction and job performance is greater than 0.6 .

In regression model, normality test aims to test the dependent variable and independent variables whether they have a normal distribution or not (Ghozali, 2011). Results from SPSS showed normal probability plot graph which both has some points spread around the diagonal line and distribution which follow the diagonal line direction. The results of this graph meet the assumptions of normality, therefore it can be stated that dependent variable and independent variables have normal data distribution.

Heteroscedasticity test aims to test whether the data in regression model will inequality ocur residual differences from one observation to another. A good regression model stated that heteroscedasticity will not happen, as seen from the distribution graph plot. The results of this study shows the scatter plot graph which the distribution of plots data seems to spread or does not collect in one corner/section. Based on that assumption, it can be concluded that this research data is homogeneous.

Descriptive statistic of job satisfaction was performed based on 20 indicators that have been set by MSQ. The average of job satisfaction showed a high yield of 3.82. Working condition, activity, and ability utilization are the highest three indicators. Social service, social status, and advancement are the three lowest indicators.

Descriptive statistic of job performance was done based on eight indicators. The average of performance showed a high yieldthat is 3.8. It means that the vast majority of employees stated by the supervisors (employees by managers, and managers by the owner) according to their performance is high.The calculation result shows the highest average yield of job performance contained in the statement of employees who do their job deftly, is based on indicator of work quality. Indicators that have the lowest average value of job performance contained in the two statements stating that employees can work well in groups and employees' actionare the indicators of cooperation and dependability.

Analysis of simple linear regression is a linear relationship between the independent variable $(\mathrm{X})$ to the dependent variable (Y). This analysis is a tool to determine the direction of the relationship between variable $X$ with variable $Y$ whether positive or negative, and to predict the value of variable $Y$ when variable $X$ value increases or decreases. Research of this analysis was conducted between $\mathrm{X}$ of job satisfaction and job performance as $\mathrm{Y}$.

The simple linear regression model in this study is $\mathrm{Y}=4,371+(-0.151) \mathrm{X}$ or $\mathrm{Y}=4.371-0,151 \mathrm{X}$. Based on simple linear regression models that already exist, it can be seen that the variables of job satisfaction (X) has a negative effect on job performance (Y). If the job satisfaction variable $(X)$ increases, job performance variable (Y) will be decreased by $0.151 \%$. If the job satisfaction variable $(\mathrm{X})$ decreases, then the job performance variable (Y) will increase by $0.151 \%$. The conclusion is that job satisfaction variable $(\mathrm{X})$ does not have a positive effect on job performance (Y).

Testing the hypothesis ( $\mathrm{t}$ test) indicates that $\mathrm{H} 0$ is accepted, seen from the results tcount of -1.033 , with the calculation of $-\mathrm{t}$ table $\leq \mathrm{t}$ count $\leq \mathrm{t}$ table then generate $\mathrm{t}$ count $\leq \mathrm{t}$ table with $-1.033 \leq 2.002$. The conclusion obtained is that job satisfaction variable partially did not affect job performance at PT XYZ.

The calculationresults for the significance value of 0.306 also show that $\mathrm{H} 0$, as seen from the results 
of significance value of 0.306 , with the calculated significance value of 0.05 , generate 0.306 more than 0.05 . The conclusion obtained is that job satisfaction variables did not affect the job performance at PT XYZ.

\section{DISCUSSION}

Job satisfaction is a positive emotional state and the evaluation resultof a person's work experience as well as the employees associated with work situations or jobs. Job satisfactions studied in this research are ability utilization, achievement, activity, advancement, authority, company policies, compensation, co-worker, creativity, independence, moral values, recognition, responsibility, security, social service, social status, HR supervision, technical supervision, variety and working condition.

Employee satisfaction is an important issue that needs to be considered in conjunction with employee productivity, and dissatisfaction which are often associated with the level of demand and high job complaints. Workers who are less noticed by the organization can lead to dissatisfaction on the employee, and with a high level of dissatisfaction in employees, it is easy for employees to encourage and conduct sabotage. This dissatisfaction is often posed in the form of frequent demonstrations. As a high turnover rate, it is often not done in the office. These employees are reluctant to learn the job description, have low motivation, tired and bored, and do not care about the environment.

Job satisfaction is an evaluation that describes someone of being happy or unhappy or a sense of satisfaction or dissatisfaction on doing the work. Job satisfaction as a generalization attitude towards work is based on several variety aspects of work, with a reminder that the level of job satisfaction experienced by each person will vary according to each individual's perception.

Job satisfaction of each employee is different to another. The questionnaire results showed that for Human Resource Department (HRD), a staff will feel very satisfied when a staff has been successful in doing his job and able to always be involved in the work, and able to have the freedom of using their own interests. In contrast to what HRD staff mentioned, E finance staff did not feel satisfaction when successfully perform the work, but the staff will be satisfied when E finance can always be involved in the work and have the freedom to use their own interests. This distinction proves that not all employees have the same sense of satisfaction and dissatisfaction at work. The feelings and needs of different employee bring a different sense of satisfaction and dissatisfaction.

The results of the questionnaire that have fulfilled by the employees mentioned that the highest job satisfaction is a satisfaction with all aspects of the work environment faced, by 4.05 . The results show the social service indicator is the lowest; this indicator saw job satisfaction of opportunities to help others. These results show that as many as 26 employees of PT XYZ mention social service indicator is unsatisfactory.

Based on the questionnaire results, it can be concluded that job satisfaction among employees at PT XYZ is not the same and have different points of satisfaction. Each employee has the points of his own in terms of job satisfaction. Other conclusions are most of the employees of PT XYZ see working condition indicator as the most satisfying indicator.

The remaining discussion is the job performance, in which is the result of work for a certain period of time and its emphasis on the results of work completed by the employee in a specific time period. Job performance is a thing as a determinant of the extent to which a person carried out his responsibilities and duties. According to Hasibuan (2007), the performance is the result of work achieved in executing the tasks assigned to them based on skills, experience, sincerity and time. Another suggestion by Suyadi Prawirosentono (2008) said that the performance is the result of work that can be achieved by a person or group of people in the organization, in accordance to authority and responsibility of each in an effort to achieve the goals of the organization in question legally, not breaking the law and in accordance with moral and ethic.

Performance is a combination of three important factors, namely the ability and interest of a worker/ employee, the ability and acceptance of the explanation of the delegation of tasks and roles, and the rate of worker motivation (Hasibuan, 2007). If the performance of each individual or employee is good, it is expected that the company's performance will go well too. Therefore, it is said that the performance is individualic, as each individual employee has different ability levels to do a task. Owner of PT XYZ has said that the performance of each employee depends on the ability of each individual. No doubt that this will require effort from the company in order to improve the performance of its employees. PT XYZ is said that by this 2014 had an increase in productivity and low turnover; the owner said that the year 2014 the overall performance of employees has grown quite well and have experienced increases.

The result of questionnaire mentions that the total average value of job performance statement is higher at 3.8. The indicatoris highest on quality of work, which is 3.97 with a statement that the employee can deftly do his job. HR Manager confirmed that most of the employees of PT XYZ are always eager to work so that no time is wasted. When indicator of quality of work results are the highest, not the case with the cooperation and depend ability indicators, the results of the questionnaire mentioned that the average value of each is 3.6. It is concluded that employees lack awareness in working with others and lack of awareness that can be trusted 
in terms of attendance and job description.

The questionnaire results can be concluded that the performance at PT XYZ among employees is not the same and vary depending on the capabilities of each employee. Each employee has their own skill level in the work. Other conclusions were that the indicator of quality of work is the indicator of the highest performance ratings for most employees of XYZ.

The questionnaire results showed that between job satisfaction and performance proved to have no positive effect (on each other). These results showed no influence of job satisfaction on job performance that is testing the hypothesis $\mathrm{H} 0$, which means job satisfaction variable has no positive influence on job performance. This can occur due to the influence of the employees who are in the comfort zone, where employees in the comfort zone makes them feel a sense of satisfaction and comfortable, until they no longer pay attention to performance and result in reduced job performance. In addition, it can be due to the placement of employees in each post does not match the capabilities of its employees. Employee feels satisfied, but with their presence in the post which is not in accordance cause imbalances in their performance.

The results supported by previous studies in Crossman \& Zaki (2006) which state that there is no significant relation between job satisfaction and job performance. As well as Margitama Branita Sandhini (2010) in the discussion of influence of job satisfaction, organizational commitment and job performance on infention of employee turnover at PT. Intraco Adhitama Surabaya, and according Packard \& Motowidlo (in Al-Ahmadi, 2009) who studied factors affecting performance of hospital nurses in Riyadh Region, Saudi Arabia, they also get the results that job satisfaction is not related to job performance, this is because the transition due the dramatic reorganization that ultimately makes the employee come under heavy pressure during this time period.

\section{CONCLUSIONS}

Based on the results of research and discussion that has been done on PT XYZ, it can be proposed that: (1) Job satisfaction comes from within each individual employee, so it is different between employees. Each individual employee will feel different satisfaction between one individual to another (2) Each employee has different levels of ability to do a task. Performance depends on the combination that exists between all ability, effort, and opportunity gained. (3) The average yield value of job satisfaction statement shows high average in total. The highest average rating of job satisfaction is indicator of working condition. The lowest average value is indicator of social service. (4) The average yield value statement job performance shows high average in total. The highest average rating of job performance is indicator of quality of work, with a statement of the employee doing his job deftly. The lowest average value of job performance is indicator of cooperative and dependability, with a statement of the employee may be working well in a team, and awareness of the actions of employees bears the risk of his work. (5) Job satisfaction does not have a positive influence on job performance in PT XYZ.

Based on the results of the research and discussion that has been done on PT XYZ, many advices and suggestions are given that may be useful as an input and evaluation to assist the development of the company further, among others (1) The leader should collect data on job satisfaction on employees on a regular basis, therefore they can exactly see statistical data and be able to correct the deficiencies experienced by the company (2) Companies need to review the position of each employee, as well as the need to provide an updated information about the company to its employees and a challenge to make employees feel more challenged and can further improve their performance (3) Enhance effective communication with all employees, through gathering, weekly or monthly morning report meetings. It is needed for socialization among employees. (4) The Company needs to socialize about career opportunities and promotions, as well as the opportunity for employees to receive education and training by taking into account the achievement, responsibility, development of individual potential and the possibility of growing.

\section{BIBLIOGRAPHY}

Abbas, Q., \& Yaqoob, S. 2009. Effect of Leadership Development on Employee Performance in Pakistan. Pakistan Economic and Social Review, 47(2), 269292.

Al-Ahmadi, H. 2009. Factors Affecting Performance of Hospital Nurses in Riyadh Region, Saudi Arabia, International Journal of Health Care Quality Assurance, 22 (1). 40-54.

Chen, X. H., Zhao, K., Liu, X., \& Dash Wu, D. 2012. Improving Employees Job Satisfaction and Innovation Performance Using Conflict Management. International Journal of Conflict Management, 23 (2), 151-172.

Crossman and Abou-Zaki 2006. Job Satisfaction and Employee Performance of Lebanese Banking Staff, Journal of Managerial Psychology, 18(4). 368376.

Ghozali, I. 2011. Aplikasi Analisis Multivariate dengan Program IBM SPSS 19-5/E.

Gomes, J. F., de Weerd-Nederhof, P. C., Pearson, A. W., \& Cunha, M. P. 2003. Is more always better? An exploration of the differential effects of functional integration on performance in new product development. Technovation, 23(3), 185-191. 
Handoko, M. L., Frances, S., van Ballegoij, J. J., Schalij, I., Bogaards, S. J., Postmus, P. E., \& VonkNoordegraaf, A. 2012. Bisoprolol delays progression towards right heart failure in experimental pulmonary hypertension. Circulation: Heart Failure, 5(1), 97105.

Hasibuan, M. S. P. 2007. Manajemen Sumber Daya Manusia. Jakarta : PT Bumi Aksara.

Hooi, Lai Wan. 2007. Human Capital Development Policies: Enhancing Employees Satisfaction. Journal of European Industrial Training, 31(4), 297-322.

Kan, Chen. 2006. Factors Affecting Job Satisfaction of Public Sector Employees in Taiwan. UMI Microform, by Pro Quest Information and Learning Company, 1(1). 4.

Keller, R. T. 2006. Transformational Leadership, Initiating Structure and Substitutes for Leadership: A Longitudinal Study of Research and Development Project Team Performance. Journal of Applied Psychology, 91(1), 202-210

Kelidbari, H. R., Dizgah, M. R., \& Yusefi, A. 2011. The Relationship Between Organization Commitment and Job Performance of Employees of Guilan Province Social Security Organization. Interdisciplinary Journal of Contemporary Research in Business, 3(6), 555.

Margitama, Branita Sandhini. 2010. Pengaruh Kepuasan Kerja, Komitmen Organisasi dan Kinerja Karyawan terhadap Turnover Intention Karyawan pada PT. Intraco Adhitama di Surabaya. Surabaya: UPN
Veteran Jatim.

Minnesota Satisfaction Questionnaire. (n.d.). Retrieved April 23, 2014, from http://www.psych.umn.edu/ psylabs/vpr/msqinf.htm

Parvin, M. M., \& Kabir, M. N. 2011. Factors affecting employee job satisfaction of pharmaceutical sector. Australian Journal of Business and Management Research, 1(9), 113.

Priyatno, D. 2010. Paham analisa statistik data dengan SPSS.

Ravizza, T., Gagliardi, B., Noé, F., Boer, K., Aronica, E., \& Vezzani, A. 2008. Innate and adaptive immunity during epileptogenesis and spontaneous seizures: evidence from experimental models and human temporal lobe epilepsy. Neurobiology of disease, 29(1), 142-160.

Suyadi, I. (2008). Pengaruh kepemimpinan, infrastruktur, pembelajaran organisatoris terhadap tehnologi, pelayanan, pasar dan merk dalam strategi ecommerce di Indonesia.

UU Republik Indonesia No. 13 Tahun 2003 Tentang Ketenagakerjaan.

Vrinda, N. N., \& Jacob, N. A. 2015. The Impact Of Job Satisfaction On Job Performance. International Journal in Commerce, IT \& Social Sciences (IJCISS) Vol, 2.

Wu, M. C., Lee, S., Cai, T., Li, Y., Boehnke, M., \& Lin, X. 2011. Rare-variant association testing for sequencing data with the sequence kernel association test. The American Journal of Human Genetics, 89(1), 82-93. 